\title{
Local IgA production in patients with chronic bronchitis: effect of acute respiratory infection
}

\section{R A STOCKLEY AND D BURNETT}

From the Department of Medicine and Immunodiagnostic Research Laboratory, Department of Immunology University of Birmingham, Edgbaston, Birmingham.

ABSTRACT The immunoglobulin A and secretory IgA concentrations were studied in the serum and sputum of patients with chronic bronchitis to determine the effect of active chest infection and inflam mation upon the estimation of local IgA production. The sputum/serum albumin ratio was higheo during chest infection $\left(5.51 ; \mathrm{SE} \pm 1.69 \times 10^{-2}\right)$ than in the non-infected samples $(0.75$ $\left.\mathrm{SE} \pm 0 \cdot 14 \times 10^{-2} ; \mathrm{p}<0.01\right)$ suggesting increased transudation as a result of inflammation. There was similar increase in sputum/serum IgA during infection from $9.47(\mathrm{SE} \pm 1 \cdot 87) \times 10^{-2}$ to $41 \cdot 2 \overrightarrow{\mathrm{B}}$ $\left(\mathrm{SE}_{ \pm} 6.92\right) \times 10^{-2}(\mathrm{p}<0.01)$. However, the proportion of IgA locally produced when assessed by conventional techniques was unchanged. There was a significant inverse relationship between the estimated local IgA production of the infected samples and the degree of inflammation $(r=-0.972$. $2 p<0.001$ ) indicating that inflammation was a major determinant of local IgA production? However, the secretory IgA concentrations of the samples were independent of the degree of inflammation. Furthermore, secretory $\operatorname{lgA}$ was found in samples that appeared to have failure of local IgA production using the method of Soutar. ${ }^{1}$ Clearer information about local IgA pro 8 duction can be obtained by measuring protein components unique to the bronchial secretions rather than applying correction factors to estimate the contribution of serum components, particularly in the presence of inflammation.

Immunoglobulin A (IgA) plays an important role in the protection of the respiratory tract. The majority of IgA in normal bronchial secretions is produced locally within the lung. ${ }^{2}$ Recurrent respiratory infections and bronchiectasis are associated with serum and local IgA deficiency. $^{3}$ Furthermore, several workers $^{145}$ have suggested that deficient "local" IgA production in the presence of normal serum IgA may be partly responsible for morbidity in chronic bronchitis.

The assessment of local IgA production is complex because of the difficulty in estimating the amount of $\operatorname{IgA}$ in the bronchial secretions that has diffused from the serum. Formulae have been derived to determine the contribution of serum $\operatorname{IgA}$ to total $\operatorname{IgA}$ in the secretion by correcting for albumin. ${ }^{6}$ It is assumed that albumin enters the bronchial secretions by passive diffusion alone and the secretion/serum

Address for reprint requests: Dr RA Stockley, Department of Medicine, University of Birmingham, Edgbaston, Birmingham B15 2TH concentration ratio reflects this ultrafiltration The amount of $\operatorname{IgA}$ derived from the serum is also dependent upon ultrafiltration and is deter mined by multiplying the serum $\operatorname{IgA}$ by the secretion/serum ratio of albumin. When the result is subtracted from the total IgA in the secretions, an estimate is obtained of the pro portion locally produced:

"local production" = IgA $(\mathrm{Br})-$

$$
\left[\frac{\mathrm{Alb}(\mathrm{Br})}{\mathrm{Alb}(\mathrm{Se})} \times \operatorname{IgA}(\mathrm{Se})\right]
$$

where $\mathrm{Br}=$ concentration in secretions, and $\mathrm{Se}=$ concentration in serum. ${ }^{6}$

However, recent work by Stockley $c^{\cdot a l^{*} \text { haso }}$ suggested that the use of such formulae ma $\bar{\Phi}$ lead to errors because they do not take int account the larger molecular size of $\operatorname{IgA}$. This may lead to an overestimate of the amount of IgA derived from serum. Furthermore, when in flammation is present the contribution of serum 
IgA to the secretions will increase and consequently that from local production will be proportionately less. These two factors may give an "apparent" reduction in local IgA production even though it remains unchanged.

The present study was designed to investigate this problem by assessing local $\operatorname{IgA}$ production in bronchitic patients with and without acute respiratory infections.

\section{Methods}

Thirty-one patients with chronic cough and sputum production were studied. All had evidence of airways obstruction (Mean $\mathrm{FEV}_{1} / \mathrm{FVC}=$ $41.9 \%$; $S D \pm 14.9 \%$ ). Eight were current smokers, 19 were ex-smokers, and the remainder had never smoked. Three patients had lifelong asthma with demonstrable reversibility of airways obstruction (greater than $20 \%$ ), and two had long standing bronchiectasis (one with a history of recurrent sinusitis).

Seventeen patients were studied during an acute chest infection. All presented acutely with increased dyspnoea and sputum production, pyrexia, lung shadowing, and significant bacterial culture. Sputum was collected over a period of four hours within three days of admission to hospital. An aliquot was sent for routine bacteriology and the remainder was ultracentrifuged $(54000 \mathrm{~g})$ for 90 minutes. The sol phase was removed and stored at $-70^{\circ} \mathrm{C}$. During the sputum collection $10 \mathrm{ml}$ of venous blood was taken, and allowed to clot. The serum was removed after centrifugation and stored at $-70^{\circ} \mathrm{C}$ until subsequent analysis.

\section{PROTEIN MEASUREMENTS}

Proteins were quantitated in all samples using radial immunodiffusion ${ }^{8}$ and monospecific antibodies (Immunodiagnostic Research Laboratory, Department of Immunology, University of Birmingham). Anti-secretory IgA was prepared by immunising sheep with secretory IgA isolated from human milk by two-dimensional electrophoresis using the method described previously. ${ }^{9}$ It was absorbed with normal human serum to eradicate cross reactivity, and checked for specificity by using immunoelectrophoresis, rocket electrophoresis, and two-dimensional electrophoresis against human whey, normal serum, and a range of diseased serum and body fluids. The potency was tested by rocket electrophoresis against other commercial antibody and the antibody is now available from Seward Laboratories. Results were expressed as a per- centage of a standard serum $(100 \%=1750 \mathrm{mg} / \mathrm{l})$ or human whey $(100 \%=5200 \mathrm{mg}$ secretory $\operatorname{IgA} / 1)$.

\section{LOCAL IGA PRODUCTION}

The proportion of locally produced $\operatorname{IgA}$ in the sputum was assessed in two ways, firstly using conventional equations and secondly by determining the sputum and secretory $\operatorname{IgA}$ ratio.

\section{Conventional equations}

Using conventional equations local production can be expressed in the following way.

Local production $=$

$$
\left[1-\frac{\operatorname{IgA}(\mathrm{Se})}{\operatorname{IgA}(\mathrm{Sp})} \times \frac{\mathrm{Alb}(\mathrm{Sp})}{\mathrm{Alb}(\mathrm{Se})}\right] \times 100
$$

where $\mathrm{Se}=$ serum concentration, and $\mathrm{Sp}=$ sputum concentration.

\section{Sputum $\operatorname{IgA} /$ secretory $\operatorname{IgA}$}

Total sputum IgA consists of varying contributions from serum and local production whereas secretory IgA reflects only the local contribution. The two results are expressed as a ratio to overcome the problem of using different standards. The ratio should vary according to the serum contribution. A higher ratio suggests a greater serum component of the total sputum $\operatorname{IgA}$.

Differences between the infected and noninfected samples were determined using a Wilcoxon rank test and correlations between local production, the degree of inflammation (expressed as sputum/serum albumin ratio), and secretory IgA were determined using the method of least squares.

\section{Results}

Three patients had low serum levels of IgA suggestive of partial deficiency $(<700 \mathrm{mg} / 1)$ and their results were omitted from the statistical analysis but are included in some of the figures for comparison. Most of the results are summarised in the table.

The infecting organism varied-Streptococcus pneumoniae (seven), Haemophilus influenzae (six), Pseudomonas aeruginosa (two), Klebsiella pneumoniae (one), unidentified gram negative bacillus (one).

SERUM AND SPUTUM IGA

All samples contained detectable amounts of $\operatorname{IgA}$. The serum IgA levels were similar in the infected and non-infected samples (table). However. the 
Table Average values for serum and sputum $\operatorname{IgA}$ and secretory $\operatorname{IgA}$ concentrations are shown together with the sputum/serum albumin ratio and sputum IgA/secretory IgA ratios. Local production was assessed using the method of Soutar. ${ }^{1}$ Results are given for infected and non-infected samples and the significance of any difference ( $p)$ is shown.

Figures in parentheses are $1 S E$.

\begin{tabular}{|c|c|c|c|}
\hline & $\begin{array}{l}\text { Infected } \\
(n=17)\end{array}$ & $\begin{array}{l}\text { Non-infected } \\
(n=20)\end{array}$ & $\begin{array}{l}\text { Significance } \\
(p)\end{array}$ \\
\hline $\begin{array}{l}\text { Serum IgA } \\
(\%)\end{array}$ & $\begin{array}{l}224 \cdot 02 \\
(33 \cdot 10)\end{array}$ & $\begin{array}{l}185.60] \\
(21.80)\end{array}$ & NS \\
\hline $\begin{array}{l}\text { Sputum IgA } \\
(\%)\end{array}$ & $\begin{array}{l}41 \cdot 21 \\
(6.92)\end{array}$ & $\begin{array}{l}9 \cdot 47 \\
(1 \cdot 87)\end{array}$ & $<0.01$ \\
\hline $\begin{array}{l}\text { Sputum/serum albumin } \\
\left(\times 10^{2}\right)\end{array}$ & $\begin{array}{l}5 \cdot 51 \\
(1.69)\end{array}$ & $\begin{array}{l}0.75 \\
(0 \cdot 14)\end{array}$ & $<0.01$ \\
\hline $\begin{array}{l}\text { Secretory IgA } \\
(\%)\end{array}$ & $\begin{array}{l}54.94 \\
(3.47)\end{array}$ & $\begin{array}{l}38 \cdot 74 \\
(4 \cdot 98)\end{array}$ & $=0.05$ \\
\hline IgA/secretory IgA & $\begin{array}{l}0 \cdot 82 \\
(0 \cdot 16)\end{array}$ & $\begin{array}{l}0.21 \\
(0.03)\end{array}$ & $=0.01$ \\
\hline $\begin{array}{l}\text { Local production } \\
(\%)\end{array}$ & $\begin{array}{l}74.99 \\
(6.61)\end{array}$ & $\begin{array}{l}77 \cdot 15 \\
(6 \cdot 72)\end{array}$ & NS \\
\hline
\end{tabular}

infected sputum samples contained more IgA than the non-infected ones resulting in a higher sputum/serum IgA ratio as shown in fig 1 $(\mathrm{p}<0.01)$. The average value for the infected samples was $20.08(\mathrm{SE} \pm 2.33) \times 10^{-2}$ and that for the non-infected was $14.34(\mathrm{SE} \pm 4 \cdot 87) \times 10^{-2}$.

\section{LOCAL PRODUCTION}

There was no difference in the average amount of local $\operatorname{IgA}$ production, as assessed by the

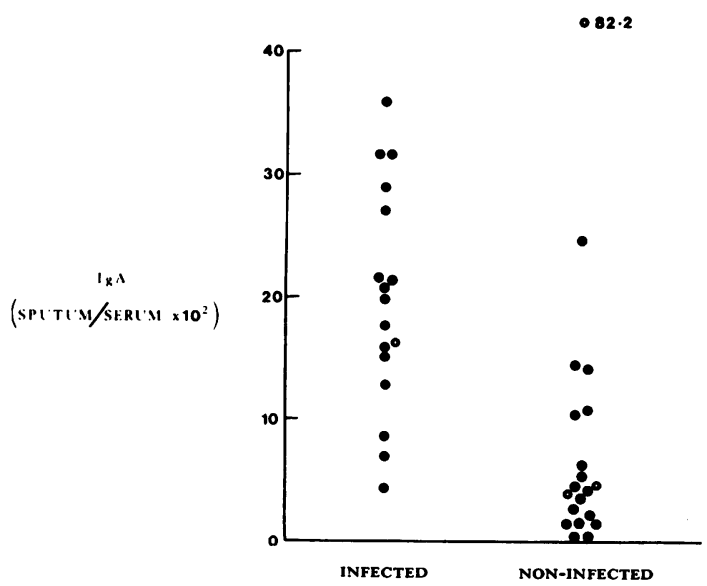

Fig 1 Sputum/serum $\operatorname{IgA}$ ratio $\left(\times 10^{2}\right)$ is shown for the infected and non-infected samples. Each point is the result from one patient. Open symbols are the patients with partial serum IgA deficiency. one of whom was studied first, with and without an infection.

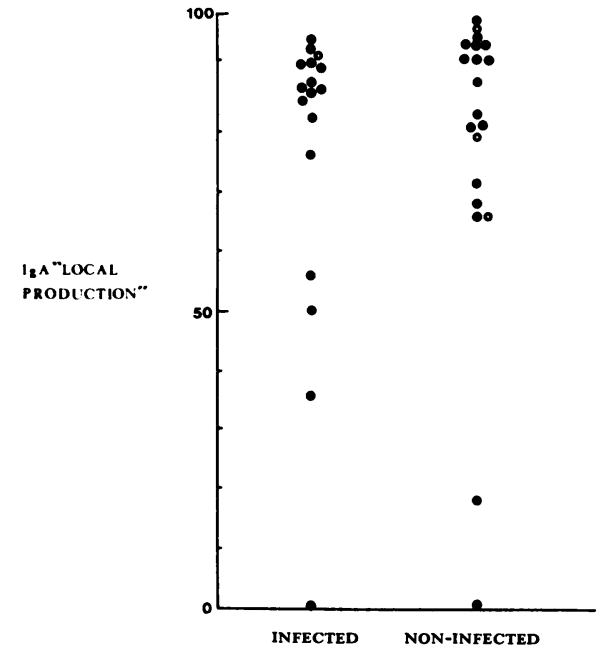

Fig 2 Percentage of total serum IgA produced locally (Soutar, 1977) is shown for the infected and non-infected samples. Symbols as in fig 1.

method of Soutar, ${ }^{1}$ between the infected and non infected samples (table). In the majority of patients local production accounted for mors than $80 \%$ of the total IgA. However, the range was wide in both groups varying from $0 \%$ t more than $95 \%$ (fig 2).

In the infected samples local production was. inversely related to the sputum/serum albumia $(2 \mathrm{p}<0.001)$. This result is summarised in fig and the relationship described by the equation:

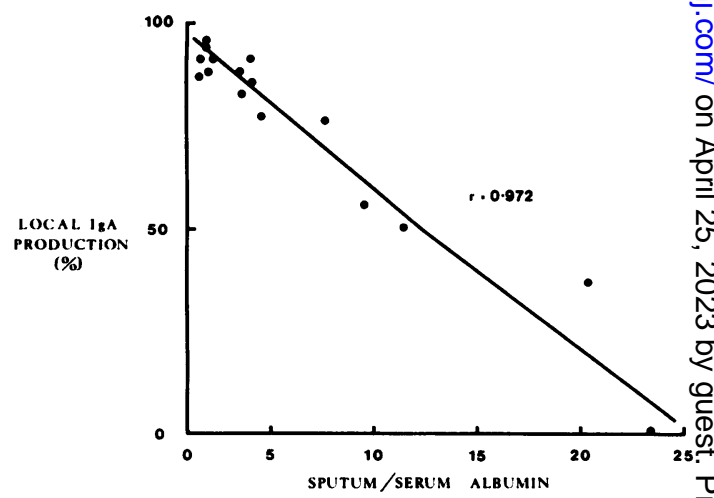

Fig 3 Relationship between estimated local production (vertical axis) and sputum/serum albumi ratio $\times 10^{2}$ (horizontal axis) is shown for the infected samples. The solid line is the regression line obtained by interpolation using the method of least squares. 


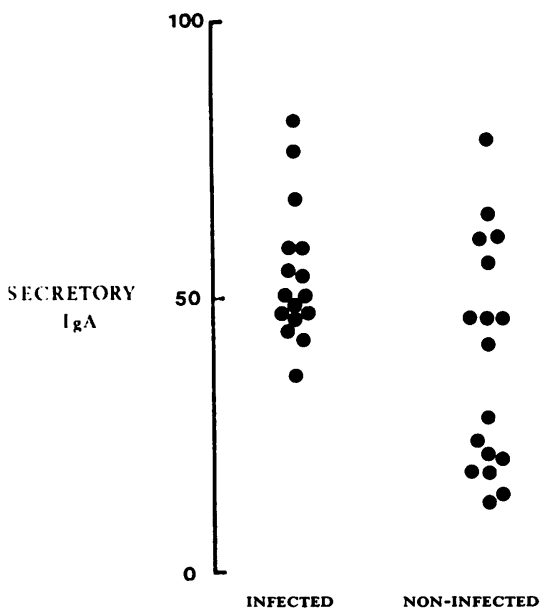

Fig 4 Secretory IgA concentrations for the infected and non-infected sputum samples.

local production $=95.89-3.62 \times$ sputum $/$ serum albumin

$$
(\mathrm{r}=-0.972)
$$

There was no relationship between sputum/ serum albumin and local production in the noninfected group. However, only two patients, one of them infected, had no "apparent" local IgA production using this method (fig 2 ).

\section{SECRETORY IGA}

All samples contained "secretory IgA" (fig 4). The concentration in the infected samples (range $35.99-91.91 \%$ ) was higher than in the noninfected samples (range $12 \cdot 86-78 \cdot 54 \%$ ). There was no relationship between the secretory IgA concentration and sputum/serum albumin ratio, local IgA production, or total sputum $\operatorname{IgA}$ in either the infected or non-infected samples. In particular the two patients whose results suggested no local $\operatorname{IgA}$ production had secretory IgA values of $42.67 \%$ (infected) and $21.76 \%$ (non-infected).

\section{SPUTUM IgA/SECRETORY IGA}

These results are summarised in the table and fig 5. The ratio was higher in the infected samples than in the non-infected ones $(p<0.01)$. There was a positive correlation between the $\operatorname{IgA} /$ secretory $\operatorname{IgA}$ ratio and sputum/serum albumin ration in the infected samples:

sputum/serum albumin $=8.29-0.98 \times \frac{\text { IgA }}{\text { Secretory IgA }}$ $(2 \mathrm{p}<0.001 ; r=0.743)$. However, this relationship was not present in the non-infected samples.

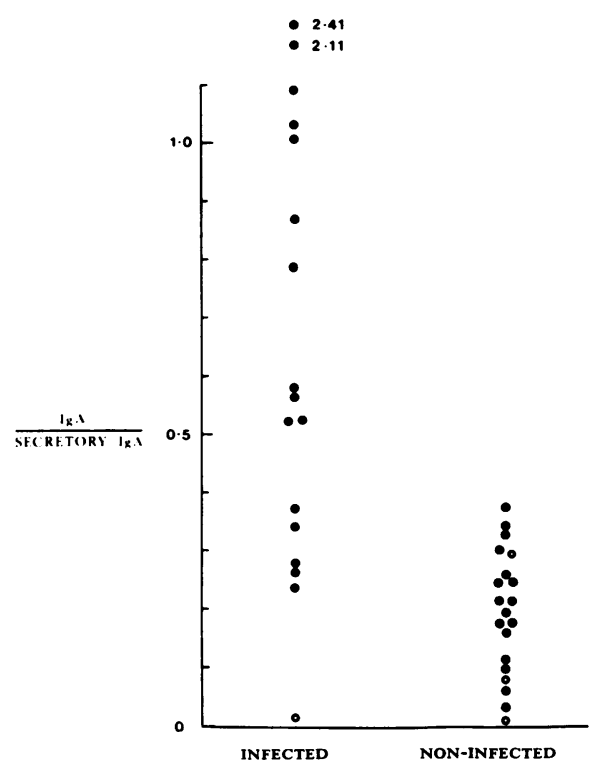

Fig 5 Ratio of total sputum IgA to secretory $\operatorname{IgA}$ is shown for the infected and non-infected samples. Symbols as in fig 1 .

\section{Discussion}

Although most of the $\operatorname{IgA}$ in normal bronchial secretions is produced locally, this may not be the case in patients with bronchitis. Soutar ${ }^{1}$ found some bronchitic patients in whom calculated local IgA production appeared to be absent, especially during illness. However, Stockley et $a l^{7}$ suggested that errors could arise when inflammation occurred resulting in increased transudation of serum $\operatorname{IgA}$ in excess of local production.

In the present study there was a higher sputum/serum albumin ratio in the infected samples (table) which would be consistent with increased protein transudation as a result of inflammation. The calculated local production was inversely related to the degree of inflammation expressed as the sputum/serum albumin ratio. This supports the hypothesis proposed at the beginning of the paper that less "apparent" local IgA production is found when the degree of protein transudation from serum rises. The relationship was not found in the non-infected samples when inflammation, and thus the serum contribution of protein, was far less.

There was no difference between the proportion of locally produced IgA in the infected and noninfected samples despite marked differences in 
protein transudation. This could be because of the wide range of values obtained and small number of patients who had marked inflammation (high sputum/serum albumin ratio). A further alternative would be comparable rises in both local and serum derived IgA during infection. However, the latter explanation is unlikely to account for the observation completely. Although secretory IgA levels were higher in the infected samples the ratio of total $\operatorname{IgA} /$ Secretory IgA was also higher suggesting that the serum component rose more than the secretory component. Further studies will be required to elucidate this point.

Secretory IgA is produced locally within the lung ${ }^{10}$ and its measurement provides a more direct approach to the study of local IgA production. No correlation was found between the calculated local IgA production and secretory IgA concentrations. In particular the two patients with "apparently" absent local IgA production using Soutar's technique had concentrations of secretory $\operatorname{IgA}$ similar to the rest of the patients. Furthermore, the measurement of secretory IgA was independent of the degree of inflammation in the infected samples, suggesting that protein transudation is less likely to produce artefacts in its assessment.

Of interest are the three patients with partial serum deficiency of $\operatorname{IgA}(30,32 \cdot 3$, and $42 \%$ of standard serum). Of these patients the first two had lifelong asthma although the latter had chronic obstructive bronchitis and radiological emphysema. None of them gave a history of recurrent upper respiratory tract infection or had evidence of bronchiectasis.

The overall conclusion is that the estimation of the presence, absence, and degree of local protein production is liable to error using conventional formulae in the presence of inflammation. It is much more relevant to measure components of the protein that are unique to the bronchial secretions such as secretory piece. However, even this may be misleading since the current technique does not distinguish free secretory piece from that bound to IgA. Further studies of the ratios of free and bound secretory piece or monomeric (serum) and dimeric (secre- tion) IgA by protein fractionation may well prove more useful in the assessment of local $\operatorname{IgA}$ C production.

We thank Professor $R$ Hoffenberg and Dr AR Bradwell for advice and encouragement, and Miss Wilma McGregor for her typing. The work $\vec{\circ}$ was supported by grants from the MedicalResearch Council, Boehringer Ingelheim, and $\vec{\rho}$ Rowbotham Bequest.

\section{References}

1 Soutar CA. Distribution of plasma cells and other cells containing immunoglobulin in the respiratory tract in chronic bronchitis. Thorax 1977; 32:387-96.

2 Reynolds HY, Newball HH. Analysis of proteins and respiratory cells obtained from human lungso by bronchial lavage. J Lab Clin Med 1974; 84: 559-73.

3 Chipps BE, Talamo RC, Winkelstein JA. IgA deficiency recurrent pneumonias, and bronchiec- $\square$ tasis. Chest 1978; 73:519-26.

4 Medici TC, Buergi $H$. The role of immunoglobulin $A$ in endogenous bronchial defence mechanisms in chronic bronchitis. Am Rev융 Respir Dis 1971; 103:784-91.

5 Clarke CW. Aspects of serum and sputum anti- $\overrightarrow{\overrightarrow{0}}$ body in chronic airways obstruction. Thorax 3 1976; 31:702-7.

6 Deuschl H, Johansson SGO. Immunoglobulinso in tracheobronchial secretion with specia reference to IgE. Clin Exp Immunol 1974; 16:0 401-12.

7 Stockley RA, Mistry M, Bradwell AR, Burnet $\mathrm{g}_{-}^{\times}$ D. A study of plasma proteins in the sol phase 3 of sputum from patients with chronic bronchitis. Thorax 1979; 34:777-82.

8 Mancini G, Carbonara AO, Heremans JF? Immunochemical quantitation of antigens by글 single radial immunodiffusion. Immunochemistry 1965; 2:235-54.

9 Bradwell AR, Burnett D, Ramsden DB, Burr WA, Princé HP, Hoffenberg R. Preparation ofr a monospecific antiserum to thyroxine binding globulin for its quantitation by rocket immuno-v electrophoresis. Clin Chim Acta 1976; 71:501-10

10 Kaltreider HB. Expression of immune mechan isms in the lung. Am Rev Respir Dis 1976; 113? 347-79. 